\title{
Constitutionalism and Political Science: Imaginative Scholarship, Unimaginative Teaching
}

Mark A. Graber

p n 1983 Martin Shapiro worried that the "new jurisprudence of values" being promoted by the new generation of public law scholars in political science would "serve as a cover for slipping back into playing "little law professor' for undergraduates." ${ }^{1}$ Proponents of the "jurisprudence of values" in political science, who engaged in constitutional theorizing about individual rights and the structure of governing institutions, would "writ[e] conventional case law doctrine" that "contain[ed] no distinctive political analysis." Worse, the fruits of the behavioral revolution might rot should normative concerns take center stage in public law inquiry. Rather than further integrate the study of courts into mainstream political science, public law scholars would spend their time telling Supreme Court justices how to do their jobs. Shapiro predicted, " $[\mathrm{P}]$ olitical scientists trained in the empirically oriented 'American politics' field will be shoved to the edges of 'public law,' and political jurisprudence will be converted to 'legal and political theory.'"2 Abandoning American constitutionalism was the best antidote for the threat a jurisprudence of values presented to the social science study of law and courts. Students of the judicial process, Shapiro declared in 1989, should explore "any public law other than constitutional law, any court other than the Supreme Court, any public lawmaker other than the judge, and any country other than the United States."3

Mark A. Graber is a professor of government at the University of Maryland, College Park and a professor of law at the University of Maryland School of Law (mgraber@gvpt.umd.edu). He is the author of Transforming Free Speech, Rethinking Abortion, and Dred Scott and the Problem of Constitutional Evil. The author thanks Rogers Smith, Howard Gillman, Keith Whittington, Ran Hirschl, Jennifer Hochschild and several (not-so) anonymous reviewers from their advice and encouragement. Apologies to the numerous talented young students of public law whose fine works were omitted to conserve space.
Recent developments in the public law subfield have confirmed some of these fears, while alleviating others. Prominent scholars continue paying disproportionate attention to American constitutional law as handed down by the Supreme Court of the United States. Twenty-nine of the forty-two awards for scholarship given out since 1990 by the Law and Courts section of the American Political Science Association have gone to works on the Supreme Court or American constitutional law. This public law scholarship, however, speaks with political science voices. Both behavioral and humanistic scholars are developing distinctive empirical and normative insights into American constitutional law, theory, and politics. Their work makes connections between ongoing constitutionalist themes and such traditional concerns of political science as political development, rational agency, comparative analysis, political institutions, and political philosophy. Law and Courts studies on the implementation of judicial decisions, sophisticated voting on constitutional courts, the interaction between elected and judicial officials, constitutional analysis outside the courts, and the broader ideological foundations of constitutional doctrine are beginning to lead, rather than always follow, academic law. A small but increasing number of distinguished law professors now borrow from public law analysis in political science to garner new insights into American constitutionalism. ${ }^{4}$

Remarkably, at a time when more academic lawyers play "little political science professor" in their scholarship, many political scientists continue playing "little law professor" when teaching basic undergraduate courses on constitutionalism. The new constitutional scholarship in public law has not made substantial inroads into the undergraduate syllabus. Undergraduates taking political science courses on constitutional law too often read the same cases and perform the same exercises as students taking second year constitutional law courses in law school. Judging from syllabi alone, the most important development in political science scholarship during the past forty years has been the additions to Robert McCloskey's classic, The American 
Supreme Court, that cover Supreme Court practice from 1960 to the present. ${ }^{5}$

The following survey identifies and proposes to remedy the present disjunction between political science scholarship and political science teaching on American constitutionalism. A renaissance is presently taking place in public law studies of con-

Remarkably, at a time when more academic

lawyers play "little political science professor" in

their scholarship, many political scientists

continue playing "little law professor" when

teaching basic undergraduate courses on

constitutionalism. approaches that make greater use of history, qualitative analysis, case studies, and normative themes have been revived. Some non-political scientists are taking notice. Several prominent historians and academic lawyers regularly engage with the scholarship produced by members of the public law field. ${ }^{7}$ Law professors dur- stitutionalism. While both behavioral and humanistic work is gaining increased attention within and without the discipline, the undergraduate political science classroom remains in a doctrinal dark age, overly focused on reading, explaining, and reproducing judicial opinions. Pedagogical progress might be made by recognizing that political scientists write about and teach constitutional politics, not constitutional law. Under that banner, professors teaching undergraduates should find more room in their basic constitutional law syllabi for exploring distinctive public law approaches to constitutionalism that combine normative and empirical analyses in ways that advance fundamental concerns of both political science and constitutionalism.

The following polemic is solely against the structure of the basic undergraduate constitutional law sequence as taught by nearly every political science department in the United States. The sequence typically consists of a class devoted to Supreme Court cases on the structure of government and a class devoted to Supreme Court cases on civil rights and liberties. Some departments offer more specialized upper-division seminars that focus more intensively on political science readings and less on case law. ${ }^{6}$ For every undergraduate who takes the more sophisticated constitutionalism course whose readings focus on public law analysis, however, probably five to ten take the constitutional law course whose readings center on doctrine. Whatever the precise numbers, the vast majority of undergraduates learning about American constitutionalism in the political science classroom spend somewhere between half and three-quarters of their time reading cases, briefing cases, and analyzing doctrine. Very little time is spent reading contemporary public law scholarship on any aspect of American constitutionalism.

\section{"The Flowers that Bloom in the Spring"}

The past twenty years have witnessed a flowering of constitutional scholarship in public law. Behavioral approaches relying on quantitative analysis and formal theory have become more sophisticated. Humanistic ing the 1970s and early 1980s turned to history in efforts to revive Warren Court jurisprudence. ${ }^{8}$ Recently, Lucas Powe and Mark Tushnet turned to political science in their attempts to explain both the Warren Court ${ }^{9}$ and the demise of Warren Court jurisprudence. ${ }^{10}$

Much contemporary political science research on American constitutionalism punctures the myth of heroic courts that routinely protect the politically powerless. Supreme Court justices, public law studies conclude, rarely disagree with policies made by the political elite, ${ }^{11}$ often pull their jurisprudential punches when they do disagree, ${ }^{12}$ and are typically ineffective when they attempt without substantial outside support to bring about fundamental political reform. ${ }^{13}$ Presidents and legislative majorities are primarily responsible for establishing judicial review and for providing justices with the tools necessary to engage in constitutional policy making. ${ }^{14}$ Judicial decisions declaring laws unconstitutional in the United States are, more often than not, facilitated by powerful political forces and serve various elite interests. ${ }^{15}$ Judicial outcomes are generally congruent with public opinion ${ }^{16}$ and more often polarize than teach. ${ }^{17}$ Challenging the common legal claim that justices have "a situational advantage over the people at large in listening for voices from the margins," 18 political scientists detail how judicial opinions rely on widespread political norms, ${ }^{19}$ including political norms that assign political statuses on the basis of race, gender, and ethnicity. $^{20}$

Gerald Rosenberg's The Hollow Hope is the most prominent work of the new constitutional scholarship, both inside and outside of political science. Through meticulously researched case studies, Rosenberg challenged those proponents of the "Dynamic Court view" who contend that "courts can effectively produce significant social change." ${ }^{21}$ Rosenberg notes that constitutional provisions intended to freeze past political commitments are poor vehicles for justifying progressive reform. As did Tocqueville, Rosenberg regards law as more often a conservative force than a means for challenging relatively enduring social practices. ${ }^{22} \mathrm{He}$ then points out that justices usually hold the same policy views as their political sponsors. After all, politicians who favor the status quo do not appoint and 
confirm justices known to prefer a new regime. ${ }^{23}$ Finally, justices who favor substantial reform lack the capacity to bring about the necessary political changes. Justices do not have the means to force recalcitrant officials to obey their decrees and often lack the knowledge necessary to bring about more desirable political states. ${ }^{24}$

The aftermath of Brown v. Board of Education (1954), Rosenberg details, demonstrates these judicial incapacities. Although the Supreme Court declared segregated schools unconstitutional in 1954, few children of color in the South attended desegregated schools until elected officials passed the Civil Rights Act of 1964, which cut off federal funds to school districts that continued to practice Jim Crow. ${ }^{25}$ The lesson of this and other case studies, Rosenberg concludes, is that political movements that rely too heavily on litigation waste valuable resources better employed mobilizing citizens for protests and electoral campaigns. ${ }^{26}$

Subsequent scholarship challenges or elaborates Rosenberg's thesis. Some works suggest that The Hollow Hope underestimates the impact of litigation campaigns. ${ }^{27}$ Michael McCann's Rights at Work details how judicial decisions influence constitutional bargains struck outside of courtrooms and help mobilize citizens for nonlitigation activities. ${ }^{28}$ The mere threat of litigation, his studies of the movement for comparative worth finds, frequently inspired businesses to make more favorable settlements with women workers. Michael Klarman suggests that Brown began the causal chain leading to integration by producing a severe backlash among Southerners that eventually forced the national government to take the affirmative steps necessary to eradicate Jim Crow. ${ }^{29}$

Political scientists use game theory to provide additional reasons for questioning the judicial capacity to champion politically unpopular causes. Building on the pioneering work of Walter Murphy, ${ }^{30}$ Lee Epstein, Jack Knight, and Thomas Walker observe how justices find legal and other excuses to refrain from challenging elected officials whenever striking down a government policy might provoke severe political retaliation. ${ }^{31}$ Challenging proponents of the popular attitudinal model of judicial decision making, who claim that justices vote their sincere policy preferences, ${ }^{32}$ proponents of the strategic model of judicial decision making insist that justices are sophisticated policy voters. "[T] he Justices cannot effectuate their own policy and institutional goals," Epstein, Knight, and Andrew Martin maintain, "without taking account of the goals and likely actions of the members of the other branches." 33 This judicial tendency to avoid sharp challenges to the incumbent regime explains why the countermajoritarian difficulty that obsesses constitutional theory in the law academy is a chimera. ${ }^{34}$ When judicial preferences diverge too sharply from the preferences of powerful elected officials, justices avoid declaring the offending government action unconstitutional. ${ }^{35}$
Judicial practice during Reconstruction provides examples of strategic judicial behavior. In 1866 the Supreme Court declared unconstitutional Abraham Lincoln's suspension of habeas corpus in the North. The majority opinion insisted that neither the national executive nor the national legislature could declare martial law in areas where courts were functioning. ${ }^{36}$ Over the next several years, however, the justices found numerous jurisdictional excuses to avoid deciding the constitutionality of legislation imposing martial law in the South, even though courts were open in the covered jurisdictions. ${ }^{37}$ These decisions cannot be explained by judicial policy preferences; Epstein and Walker point to much evidence indicating that a judicial majority objected to martial law in both North and South. The justices behaved differently in the 1866 case than in subsequent cases, they maintain, because the strategic environment for judicial policy making had changed. Martial law in the North had been abandoned when the justices declared that policy unconstitutional, but the Reconstruction Congress would have retaliated against a tribunal that interfered with martial law in the South.

Rational choice perspectives provide other insights into the judicial process. Justices negotiate among themselves as well as with outside officials. Forrest Maltzman, James Spriggs, and Paul Wahlbeck detail the strategic bargaining that takes place when judicial opinions are crafted. Their research suggests that legal calls for principled opinions are unrealistic. Judicial writing is typically a committee product that incompletely harmonizes quite different understandings of the law and the judicial function. ${ }^{38}$ James Rogers offers a game theoretic explanation for legislative willingness to tolerate the judicial power to declare legislation unconstitutional: sympathetic justices ensure that laws serve their legislative purposes. When elected officials believe the judicial majority shares their general policy preferences and that justices have "better information on the actual impact of the law relative to that available to Congress when it enacted the law," then legislative policy commitments are best advanced by authorizing judicial review of legislation. ${ }^{39}$ Courts typically strike down laws, in this view, that elected officials would repeal had they been as well informed as the justices. Congress will even tolerate some instances of judicial review when legislative and judicial preferences diverge, as long as elected officials believe that justices most often declare unconstitutional legislation that in practice is not serving its original legislative purpose. ${ }^{40}$

More humanistic political science studies further undermine anxieties about the countermajoritarian difficulty by highlighting the political foundations of judicial review. Challenging ritual incantations that "when the Supreme Court declares unconstitutional a legislative act or the action of an elected executive, it thwarts the will of representatives of the actual people of the here and now," ${ }^{41}$ scholarship in public law documents how "the 
representatives of the actual people of the here and now" facilitate judicial review to advance shared constitutional visions, to avoid taking responsibility for certain contested issues, such as abortion and slavery, and to entrench politically vulnerable measures. ${ }^{42}$ Howard Gillman's important study of late-nineteenth-century constitutional politics illustrates how electoral/judicial alliances are established and function. His essay details the ways Republicans in the wake of Reconstruction dramatically expanded judicial power in order to rationalize the emerging industrial order. ${ }^{43}$ Abandoning conventional efforts to "discuss judicial power as if it were a by-product of essentially legal choices that relatively independent judges make about the proper scope of their authority," he asserts, "the expansion of federal judicial power in the late-nineteenth century is best understood as the sort of familiar partisan or programmatic entrenchment that we frequently associate with legislative delegations to executive or quasi-executive agencies." Republican Party officials committed to "national economic development" took two steps to facilitate favorable judicial policy making. First, they sponsored the Judiciary Acts of 1875 and 1891. These statutes dramatically expanded federal court jurisdiction over the legal issues raised by railroads and other corporations engaged in national commercial activities. Second, Republicans staffed the federal judiciary with corporate lawyers, many of whom had close connections to the railroads. Subsequent Supreme Court judicial decisions sharply limiting antitrust prosecutions, striking down the federal income tax, issuing injunctions against labor unions, and banning state regulation of interstate railroads, ${ }^{44}$ Gillman concludes, "are best viewed as 'politically inspired," " as "part of the Republican Party's effort to restructure national institutions better to facilitate national economic development." ${ }^{45}$

Other political science studies further elaborate how judicial power in the United States rests on support from executives, legislators, and political movements. Kevin McMahon explores how decisions by the Roosevelt, Truman, and Eisenhower administrations facilitated the Supreme Court's decision in Brown v. Board of Education. $^{46}$ J. Mitchell Pickering and Cornell Clayton detail the political foundations for Rehnquist Court decisions that imposed federalism limits on national power. ${ }^{47}$ Keith Whittington documents the tendency for judicial supremacy - the view that justices have the final authority to determine what the Constitution means- to be championed by leaders of decaying political coalitions who must rely on the federal judiciary to buttress policies that no longer command powerful electoral support. When uniting Southern and Northern Jacksonians in Congress became more difficult, prominent Democrats before the Civil War began to insist that the Supreme Court had the sole power to determine the constitutional status of slavery in the territories. Judicial authority is typically challenged, Whittington notes, only when emerging political coalitions must overturn past court rulings to establish their own constitutional visions and authority. Lincoln took a different position on judicial supremacy than James Buchanan because he occupied a different position in political time. ${ }^{48}$ Several political scientists observe that interestgroup activity is often a prerequisite for the exercise of judicial power. Susan Lawrence and Charles Epp, for example, conclude that the Supreme Court protects the rights of the poor and various civil liberties only when powerful political forces engage in long, expensive litigation campaigns. These campaigns are often supported by elite actors within the national government. Favorable Supreme Court decisions on welfare rights, Lawrence points out, were consequences of dramatically increased funding for legal services during the late 1960s. ${ }^{49}$

Comparative constitutional studies similarly find a global explosion of judicial review more rooted in electoral politics than in judicial independence. Ran Hirschl's "hegemonic preservation thesis" details how the rise of judicial review in Israel, South Africa, Canada, New Zealand, and many other countries resulted from actions taken by elected officials and interest groups fearful of losing political power. ${ }^{50}$ His Toward Juristocracy describes how in recent years "constitutional reform" has served as a vehicle for "tranferr(ing) an unprecedented amount of power from representative institutions to judiciaries." ${ }^{51}$ As is the case in the United States, judicial review is best conceptualized as resulting from cooperation between justices and other governing officials, rather than as a means by which an apolitical judiciary checks the rest of the political system. "When their policy preferences have been, or are likely to be, increasingly challenged in majoritarian decisionmaking arenas," Hirschl observes, "elites that possess disproportionate access to, and influence over, the legal arena may initiate a constitutional entrenchment of rights and judicial review in order to transfer power to supreme courts." 52 Fulfilling this constitutional mission, courts throughout the world are more likely to strike down legislation that limits liberties exercised by the politically powerful than to protect powerless minorities. Thus, the right to make unlimited campaign contributions is presently gaining more judicial solicitude worldwide than rights to basic necessities. Hirschl's study of comparative constitutional law in action "contrast(s) the limited impact of constitutionalization on enhancing the life conditions of the have-nots with its significant contribution to the removal of so-called market rigidities and the promotion of economic liberties." 53

Other comparative studies document numerous political dimensions of the global constitutional experience. Exploring the legislative politics underlying the establishment of constitutional courts in Western Europe, Alec Stone Sweet finds that judicial review is more often established by legislative edict than judicial decree. ${ }^{54}$ The strategic model of judicial decision making is being exported 
with much success. ${ }^{55}$ James Gibson, Greg Caldeira, and Vanessa Baird detail how the concepts of specific and diffuse support for courts developed in the United States help explain public attitudes toward national courts throughout Europe. Elites throughout the world, they find, are inclined to trust courts when they approve of the actual trend of judicial decisions in their society (specific support), while average citizens who typically know very little about specific court decisions are more inclined to trust courts as generally committed to the rule of law (diffuse support). ${ }^{56}$

Many works, conversely, use insights from comparative constitutionalism to explain dimensions of American constitutionalism. Leslie Goldstein claims the strong veto powers given to nations in the European Union partly explains why contemporary decisions by the European Court of Justice limiting the power of nation states provoke less resistance to judicial authority than did analogous decisions by the early-nineteenth-century Marshall Court that were routinely ignored by local officials. ${ }^{57}$ Gary Jacobsohn explains differences in religious freedom in India, Israel, and the United States as consequences of respective constitutional efforts to disestablish a previously established religion, maintain an established religion, and prevent any religion from becoming established. ${ }^{58}$ A different comparative focus is provided by important work recently published on constitutionalism in the fifty states. ${ }^{59}$

Other areas of public law research on constitutionalism might be highlighted. The attitudinal model remains vibrant; ${ }^{60}$ Dan Pinello has published a sophisticated analysis linking judicial votes in gay rights cases to a variety of demographic and political factors. ${ }^{61}$ Political scientists have authored influential studies on the processes by which federal justices are nominated and confirmed. ${ }^{62}$ Members of the Princeton school of constitutional thought produce fascinating work offering more philosophical perspectives on American constitutionalism. ${ }^{63}$ Political scientists sympathetic with originalism have sparked important controversies with their investigations into Marbury v. Madison (1803), the origins of American constitutionalism, and the changing nature of American judicial review. ${ }^{64}$ Studies of individual justices remain popular, ${ }^{65}$ as do studies of particular areas of constitutional policy making. Donald Downs has written fascinating accounts of the politics underlying debates over free speech. ${ }^{66}$ Douglas Reed has recently surveyed the constitutional politics of educational financing. ${ }^{67}$ While most political scientists emphasize the instrumental uses of constitutional rhetoric, John Brigham observes how constitutional norms shape the way political actors conceptualize their institution's roles and their political interests. ${ }^{68}$

The constitution outside the courts is a growth industry in political science. Pioneering works by Louis Fisher, Sanford Levinson, John Agresto, Sotorios Barber, and Susan Burgess highlight constitutional interpretation by presi- dents, legislators, and political activists. ${ }^{69}$ Official constitutional meanings at any moment in time, they point out, usually result from dialogues between justices and elected officials. When solos are performed, the artist is most often the president. Whittington points out that on such constitutional matters as the appropriate standard for impeaching Supreme Court justices, only Congress has made constitutional decisions. Those decisions are regarded as having similar precedential value as analogous judicial rulings. ${ }^{70}$ John Dinan elaborates numerous instances where legislators better protected constitutional rights than justices. $^{71}$

Foregoing traditional doctrinal approaches to constitutional law, political scientists document how broader currents of American political thought influence constitutional development inside and outside of courts. Gillman demonstrates that the judicial decisions protecting freedom of contract at the turn of the twentieth century are better explained by the historical animus against class legislation than by Social Darwinist notions of laissez-faire. ${ }^{72}$ Rogers Smith details how judicial decisions reflect changing conceptions of American liberalism. ${ }^{73}$ A flourishing school of feminist thought in political science is exploring the influence of gender in American constitutional development. Julie Novkov explains how concepts originally employed to justify protective legislation for women provided problematic constitutional foundations for the entire regulatory state during the New Deal. ${ }^{74}$ Judith Baer's work highlights the continuing importance of gender in numerous areas of American constitutional law. ${ }^{75}$

\section{"Have Nothing to Do with the Case"}

The public law scholars who offer these original political science perspectives on constitutionalism revert to playing little law professor when they teach the basic constitutional law sequence. The primary text in the standard upper-level course on American constitutionalism is a casebook. The primary readings are judicial opinions. Professors rarely assign their own innovative scholarship or any contemporary works by political scientists on American constitutionalism. Written assignments are often case briefs, legal briefs, or mock judicial opinions. Despite the great diversity of methodological approaches in the public law field, assignments look alike. Few political science professors would have to do much more than change the order of their lectures were they required to teach from another professor's syllabi. $^{76}$

Doctrine dominates the requiring reading in political science courses on American constitutionalism. With rare exceptions (Grossman 2003; Kahn 2003; Whittington 1998), far more than half the assigned readings in the basic constitutionalism sequence are cases. Many courses are devoted entirely to judicial decisions. Few syllabi even do justice to the professor's preferred perspective. ${ }^{77}$ Leading 
behavioralists fail to assign scholarship on the attitudinal and strategic models of judicial decision-making. Humanists fail to assign any contemporary study of American constitutional development.

Political science does seep into undergraduate constitutional law courses. Political science perspectives are offered during lectures and tested on during examinations. Most professors use a casebook edited by political scientists. The introductions, marginal notes, and selections for further readings in these works offer a glimpse of non-legal perspectives on constitutionalism. While many professors rely exclusively on cases or casebooks, most require supplemental reading. The most popular supplement, Robert McCloskey and Sanford Levinson's The American Supreme Court (2000), can be used to explore attitudinal, strategic, and legal perspectives on judicial decision making. ${ }^{78}$ Relying on a work first published in 1960 to present contemporary political science perspectives on constitutionalism, however, is the pedagogical equivalent of relying exclusively on The American Voter to present contemporary political science perspectives on voting behavior. ${ }^{79}$

Judicial writings have an important place in the political science curriculum - they just should not have the near exclusive place of honor. Students should be taught how to read the lengthy excerpts from judicial opinions regularly published in major newspapers. Opinions call attention to broader currents in American political thought, highlight important elements of American political development, and provide grist for class discussions on contested questions of civil liberties and government power. Efforts to explain judicial decisions require some attention to the explanations justices give for their rulings. These reasons for including judicial opinions, however, hardly justify the extensive attention given to judicial opinions in almost every basic course on constitutionalism. Too obsessed with legal writing, most public law syllabi surveyed include much material that students do not understand and political scientists are not prepared to teach.

Justice Oliver Wendell Holmes's famous dissent in Abrams v. United States (1919) illustrates some difficulties with assigning lengthy excerpts from judicial opinions in undergraduate classes. Jacob Abrams was convicted under the Sedition Act of 1918 after he called for a general strike protesting American intervention in the Russian Revolution. The judicial majority in Abrams sustained the conviction, even though the Sedition Act only punished efforts to interfere with the war effort against Germany. The judicial majority reasoned that Abrams knew that a general strike would interfere with all military engagements abroad, not just American interference with the Russian Revolution. Justice Holmes disagreed. Most political science courses on civil liberties sensibly require students to read the famous passage in the Holmes dissent in which the justice declared, "[T] he best test of truth is the power of the thought to get itself accepted in the competition of the market." ${ }^{80}$ Students are also, however, assigned the less famous sections, interpreting the Sedition Act of 1918 as requiring a specific intention to interfere with the war against Germany. ${ }^{81}$ The latter passages sow confusion. Second-year law students who have previously taken a course in criminal law may understand the theory of criminal attempt underlying the legal reasons Holmes gives for insisting that Jacob Abrams could not be punished under the Sedition Act of 1918. Few undergraduates are similarly prepared. Whether a majority of political science professors have a working knowledge of the common law of criminal attempts is doubtful. Those who do are unlikely to spend scarce class time imparting that knowledge to students. If students are unlikely to understand the legal argument interpreting the Sedition Act, and professors are unlikely to explain the legal argument, what is the point of assigning that legal argument?

Similar problems of competence and preparation exist throughout the undergraduate syllabus. Most constitutional law classes begin with Marbury v. Madison (1803), the first instance of the Supreme Court discussing at length the judicial power to declare laws unconstitutional. The assigned excerpts from Marbury in all constitutional law texts include lengthy discussion of jurisdictional issues associated with writs of mandamus and appellate practice likely to be incomprehensible to students who have not had first-year civil procedure. Supreme Court opinions interpreting the provision in the Fifth Amendment that declares " $[\mathrm{N}]$ or shall private property be taken for public use, without just compensation" assume knowledge of basic concepts taught in first-year law courses on property. Few undergraduates understand the reference to "background principles of nuisance" that plays a crucial role in Lucas $v$. South Carolina Coastal Council (1992), a commonly assigned case. The constitutional law of libel rests on common law tort principles. Most undergraduates do not know what a tort is. Hardly any understand the legal differences between "recklessness" and "negligence," which, assigned cases inform them, are crucial to determining when private and public figures may obtain damages in defamation suits. ${ }^{82}$

Written assignments promise further confusion. With rare exceptions, the professors who require undergraduate students to write legal briefs, participate in moot court exercises, or pen a mock judicial opinion have never litigated a case, engaged in oral argument, or been a judicial clerk. The average undergraduate "brief" is an essay on some point of constitutional law that only dimly corresponds to what advocates submit to judicial tribunals. No syllabi examined for this review suggests that undergraduates learn the distinctive brief-writing skills routinely taught in first year legal writing. Having undergraduates do written and oral presentations is part of good teaching. Still, claims that students in political science courses learn legal writing and legal advocacy are misleading at best. 
Overall, the standard constitutional law/civil liberties class largely provides an inferior overview of materials that will be taught with far more skill in law school. Undergraduates are repeatedly confronted with opinions they cannot adequately comprehend and pseudo-legal assignments outside their instructors' area of expertise. Whether such a curriculum would make pedagogical sense if most students in undergraduate constitutional law classes did not plan to attend law school is doubtful. And given the high percentages of students who will reprise constitutional law within three years, most constitutional law courses in political science are educationally redundant.

Labels matter. Political scientists inherit courses entitled "Constitutional Law I: Structure of Government" and "Constitutional Law II: Civil Rights and Liberties." Assistant professors who receive this bequest assume they are supposed to teach constitutional law. Besides, political scientists from their academic infancy learn that constitutional law is about judicial opinions. They are taught constitutional law as undergraduates and lead discussions on constitutional law when graduate section leaders. This pedagogical inertia explains why constitutional law courses assign lengthy excerpts from Justice Holmes's dissent in Abrams, even though very few political scientists claim particular expertise in doctrinal analysis, while ignoring The Hollow Hope, even though most political scientists teaching these courses do have particular expertise on the effect of judicial decisions. Courses labeled "Constitutional Politics" might inspire different assignments. Judicial capacity to produce progressive reform is clearly an issue for constitutional politics. The details of Holmes's Abrams dissent is not.

\section{From Constitutional Law to Constitutional Politics}

Public law courses on the structure of government and civil liberties should emphasize constitutionalism, not law. Professors who associate constitutionalism with limited government ${ }^{83}$ should assign scholarship examining various restraints on government power and the capacity of different institutions to enforce those restrictions. More sophisticated conceptions of constitutionalism recognize that constitutions empower as well as limit. ${ }^{84}$ "The vigor of government," Alexander Hamilton pointed out in Federalist 1, "is essential to the security of liberty." 85 Courses devoted to more positive conceptions of constitutionalism could explore the goals and aspirations of particular constitutional orders, the institutions thought necessary to achieve those goals and aspirations, and the people assumed to share those goals and operate the relevant institutions. ${ }^{86}$ Constitutional issues associated with the contemporary welfare state encourage discussions on the best constitutional understanding of equality, whether federalism promotes democratic experimentation or races to the bottom, and the ways popular beliefs about political economy influence constitutional policy making. A constitutionalism conceived so broadly encompasses all political science and many other disciplines. ${ }^{87}$ Fortunately, manageable political science courses can easily be organized around particular constitutional concerns.

"The Supreme Court in the Constitutional Order" and "Enforcing Constitutional Rights and Limitations" are two such courses. Readings for the first help students evaluate theories about what courts should do in light of political science research on what courts have done and are capable of doing. Appropriate texts include a recent anthology on Supreme Court decision making, ${ }^{88}$ the leading work on the attitudinal model of judicial decision making, ${ }^{89}$ the leading work on the strategic model of judicial decision making, ${ }^{90}$ a collection of essays exploring historical and legal understandings of judicial decision making, ${ }^{11}$ a study on the process by which justices are appointed and confirmed, ${ }^{92}$ Rosenberg's 1991 work on the impact of Supreme Court decisions, a political history of the Supreme Court, ${ }^{93}$ and a smattering of judicial opinions discussing judicial power or illustrating judicial policy making. Readings for the second explore how various institutions, including but not limited to the judiciary, protect various constitutional rights and restrain government actors. Appropriate works include The Federalist Papers, contemporary defenses ${ }^{94}$ and criticisms $^{95}$ of existing constitutional institutions, a collection of essays exploring different ways constitutions protect rights, ${ }^{96}$ Dinan's 1998 work evaluating the relative capacity of justices and elected officials to protect rights, Whittington's study of constitutional debate by elected officials, ${ }^{97}$ Gordon Silverstein's analysis of the constitutional separation of powers, ${ }^{98}$ Goldstein's 2001 work comparing constitutional protections for federalism in Europe and the United States, and a smattering of judicial opinions discussing or illustrating judicial capacity to protect rights and limit government.

Numerous other organizing themes are possible. Courses in constitutionalism might have separate units considering the political foundations of judicial review, strategic behavior by justices, comparative constitutionalism, and other issues. These topics may inhibit the common tendency to divide the constitutional universe into political institutions and civil liberties, a division that ignores how political institutions are designed to privilege certain civil rights and liberties. ${ }^{99}$ An historically minded political scientist might teach a two-term sequence comprising a course on constitutional development and a course on contemporary constitutional problems.

Terri Peretti's In Defense of a Political Court is a far better core text for undergraduate courses on constitutional law than the standard casebook. It combines a behavioral perspective on judicial behavior with a normative analysis of the judicial function. Peretti regards justices as 
unalloyed policy makers who consistently base judicial decisions entirely on policy preferences. In her view, " $[T]$ he evidence is compelling that policy making on the Supreme Court is a reflection of the ideological preferences of the justices." ${ }^{100}$ A tribunal engaged in naked policy making, she insists, promotes such desirable ends as political participation and pluralism. "The opportunities for groups to gain access to and have an effective voice in government policymaking are greatly expanded," Peretti writes, when courts have the power to declare laws unconstitutional. ${ }^{101}$ The more political the court, the more democratic the constitutional politics. Peretti concludes, " $[\mathrm{P}]$ olitical motive in constitutional decisionmaking ensures that the Court exercises its power in a politically responsible and democratically defensible manner." ${ }^{102}$

Numerous political science works examining the practice and theory of constitutionalism might be packaged with In Defense of a Political Court. Ronald Kahn's The Supreme Court and Constitutional Theory, 1953-1993 provides an account of contemporary judicial decision making that is more legal than Peretti's. Kahn insists that justices make decisions on the basis of constitutional principles "because they view the Court as a countermajoritarian legal institution and share a concern for the legitimacy of the Supreme Court and the rule of law." ${ }^{103}$ Hirschl's Toward Juristocracy, discussed above, questions whether judicial review promotes pluralism and participation. Courts, in his view, secure elite interests. The Federalist Papers might promote discussions about whether political participation or government by the best persons is the more vital constitutional value in the United States. ${ }^{104}$ Students' tendency to assume that their values are constitutional values ${ }^{105}$ can be combated by requiring Constitutional Stupidities, Constitutional Tragedies. ${ }^{106}$ This anthology regards numerous constitutional institutions as badly flawed and desperately needing reform. "How," Suzanna Sherry asks in one essay, "can a democratic nation tolerate a Senate in which the largest state has more than sixty-five times the population of the smallest and yet each has two senators?" 107 Such readings better prepare students for law school and citizens for political life than courses that place greater emphasis on such legal technicalities as the negative radiations of the commerce clause ${ }^{108}$ and the aptly named three-part Lemon test. ${ }^{109}$

Constitutional politics restores normative concerns to public law analysis without taking sides in the methodological debates presently exciting political science. All theories of constitutionalism make empirical assumptions-assumptions that political scientists can expose, explore, and explode. The grand constitutional theory tradition begun during the 1950 s by Herbert Wechsler ${ }^{110}$ and Alexander Bickel ${ }^{111}$ assumes that justices have unique capacities to decide policy questions on the basis of fundamental values. ${ }^{112}$ The attitudinal model, studies on the political foundations of judicial review, and scholarship on the constitution outside the courts question this pervasive vision of judicial review as principled justices standing up to unprincipled elected officials. "Immortal principles fly their standards in judicial opinions," Thomas Reed Powell noted almost a century ago, "[b] ut so they do in the common every-day talk of the butcher and banker, of the suffragist and the anti-suffragist, the pacifist and the militarist, the Socialist and the individualist." 113

Rather than hypothesize ideal states, students taking constitutional politics should explore the institutions necessary to pursue desirable ends and the extent to which present institutions serve or are capable of being reformed to serve those purposes. Constitutionalism classes taking a political science perspective should encourage identification of good constitutional practices and the institutional prerequisites for securing them. Students debating whether the president is constitutionally authorized to send troops into foreign combat in the absence of a Congressional declaration of war would be asked to consider whether contemporary legislators have the political capacities and incentives necessary to oppose presidential wars. Those who rail against a jurisprudence of values should remember that in the absence of a theory about normatively desirable states of affairs only morbid curiosity explains the choice to study judicial votes rather than judicial toenails.

That undergraduate courses on constitutionalism are overpopulated by pre-laws does not justify teaching a preview of coming attractions. Medical educators encourage undergraduates to take courses on medical humanities that provide critical overviews on subjects taught in medical school. The political science curriculum should similarly provide pre-law and other students with critical behavioral, rational, and humanistic social science perspectives on the law and courts. Doctrinal analysis and legal writing are best left to law professors who specialize in doctrinal analysis and legal writing. Political science courses on the Supreme Court should explore the role that tribunal has historically played in American politics, the political foundations of contemporary judicial practice, and the broader political changes necessary for the judiciary to play some other function. ${ }^{114}$ Courses on constitutional powers and rights should examine the political foundations of limited government, the constitutional understandings privileged by the present array of governing institutions, the institutions necessary to privilege a more desirable set of constitutional understandings, and the means, if any, by which the constitutional system might be reformed to privilege that more desirable set of constitutional understandings. Political scientists teaching constitutional law will find a wealth of political science materials when they adopt these and other perspectives on constitutionalism. Little more is needed than a commitment to preach faithfully in the classroom what we practice religiously in our scholarship. 


\section{Appendix}

\section{Specialty seminars}

Calvert, Randall. Washington University, St. Louis. Fall 2004. Constitutional politics in the United States. http://artsci.wustl.edu/ polisci/calvert/PolSci3103.

Levy, Jacob T. University of Chicago. Spring 2001. Constitutionalism (combined graduate and undergraduate course).

Whittington, Keith E. Princeton University. Spring 1998. Constitutional theory.

\section{Cases or casebook only}

Baer, Judith. Texas A\&M University. Spring 2002. Constitutional developments.

Davis, Jeffrey. University of Maryland, Baltimore. Spring 2003. American constitutional law.

Epstein, Lee. Washington University. Spring 2001. Constitutional law.

Graber, Mark A. University of Maryland, College Park. Fall 2002. Constitutional law.

Keck, Tom. Syracuse University. N.d. Constitutional law II.

Lermack, Paul. Bradley University. January 2003. Political science 460 .

Lopeman, Sam. State University of West Georgia. Fall 2000. Constitutional law I.

Powers, Thomas. University of Minnesota-Duluth. Spring 2003. American constitutional law II: Civil liberties.

Schweber, Howard. University of Wisconsin. Spring 2003. Constitutional law.

Segel, Jeffrey. State University of New York at Stony Brook. N.d. Constitutional law.

Zorn, Christopher. Emory University. Spring 2003. Civil liberties.

\section{Cases or casebook plus one other book}

Dean, Karen, Illinois College. N.d. Civil liberties.

Dehnel. Dave. Augustana College. Winter 2001-2. Constitutional law I.

Foster, James. Oregon State University. Fall 2002. American constitutional law.

Fruchtman, Jack. Towson University. Spring 2003. Constitutional law II

Gillman, Howard. University of Southern California. Fall 2003. Constitutional law.

Jacobsohn, G.J., Williams College. Fall 2001. Constitutional law (I).

Kessler, Mark. Bates College. Winter 2001-2. Constitutional freedoms.

O’Brien, David M. University of Virginia. Spring 2003. Civil rights and civil liberties.

Reisert, Joseph R. Colby College. Fall 2002. Constitutional law I.
Swinford, Bill. University of Richmond. N.d. Civil rights and liberties.

\section{Cases or casebook plus more than one outside} reading, but dominant assignments are cases

Arkes, Hadley. Amherst College. Fall 2001. The American Constitution II.

Finn, John E. Wesleyan University. Spring 2001. American constitutional interpretation.

Fruchtman, Jack. Towson University. Fall 1999. Constitutional law I.

Gillman, Howard. University of Southern California. Fall 2001. Constitutional law.

Jacobsohn, G.J. Williams College. Spring 2003. Constitutional Law (II).

Kessler, Mark. Bates College. Winter 2002-3. Race and civil rights in constitutional interpretation.

Kobylka, Joseph. Southern Methodist University. Spring 2002. The constitutional law of civil liberties.

Puro, Steven. St. Louis University. Fall 2002. American constitutional law.

Smith, Kimberly. Carleton College. Spring 2002. American constitutional law II (a history text, but a high percentage of assignments appear to be cases).

Smith, Rogers M. University of Pennsylvania. Fall 2002. American constitutional law.

Weber, Paul J. University of Louisville. Fall 2001. Constitutional law.

\section{Casebook plus numerous (mostly) law review essays}

Kahn, Ronald. Oberlin University. Spring 2003. American constitutional law.

\section{Casebook plus substantial political science readings}

Grossman, Joel. Johns Hopkins University. Spring 2003. Constitutional law.

Whittington, Keith E. Princeton University. Fall 1998. Constitutional interpretation.

\section{Notes}

1 Shapiro $1983,543$.

2 Ibid., 543-44.

3 Shapiro 1989, 102.

4 How well these law professors make use of political science scholarship is contestable. Compare Rosenberg 2000 with Graber 2002.

5 McCloskey 2000. Sanford Levinson emphasizes that he made "the basic decision to add to, rather than genuinely revise, [McCloskey's] book." Levinson 2000, ix.

6 See, for example, the "specialty seminars" listed in the appendix.

7 Eskridge 1991; Cross 1997; Griffin 1996; Stearns 2000; Klarman 1996.

8 Kalman 1996. 
9 Powe 2000.

10 Tushnet 1999; see also Sunstein 1999.

11 The seminal work in this literature is Dahl 1957.

12 Epstein and Knight 1998.

13 Rosenberg 1991.

14 Graber 2003.

15 Graber 1993; Hirschl 2004.

16 Marshall 1989; Mishler and Sheehan 1993.

17 Franklin and Kosaki 1989.

18 Fiss 1989, 255; Michelman 1988, 1537.

19 Smith 1985.

20 Smith 1997.

21 Rosenberg 1991, 31.

22 Tocqueville 1990, 272-80; Rosenberg 1991, 10-13.

23 Rosenberg 1991, 13-15.

24 Ibid., 15-21.

25 Ibid., 39-169.

26 Ibid., 336-43.

27 Schultz 1998. For an excellent study of the judicial capacity to produce social change with less emphasis on constitutional issues, see Feeley and Rubin 1998.

28 McCann 1994.

29 Klarman 1994. See also Klarman 2001.

30 Murphy 1964.

31 The seminal works in the strategic tradition are Epstein and Knight 1998; Epstein and Knight 1999; Epstein and Walker 1995; Knight and Epstein 1996. See also Cross 1998, 513 nn. 8-10, citing numerous articles on judicial strategy published by positive political theorists.

32 Segal and Spaeth 1993; Segal and Spaeth 2002.

33 Epstein, Knight, and Martin 2001, 585.

34 Friedman 2002.

35 Epstein, Knight, and Martin 2001.

36 Ex parte Milligan.

37 Exparte McCardle; Georgia v. Stanton; Mississippi v. Johnson.

38 Maltzman, Spriggs, and Wahlbeck 2000.

39 Rogers 2001, 87.

40 Ibid., 94.

41 Bickel 1962, 16-17.

42 Graber 1993; Silverstein and Ginsberg 1987; Whittington 2003.

43 Gillman 2002.

44 The decisions are, respectively, United States v. E.C. Knight Co.; Pollock v. Farmers' Loan and Trust Co.; In re Debs; and Wabash, St. Louis \& Pacific Railway Co. v. Illinois.

45 Gillman 2002, 511, 512.

46 McMahon 2004.

47 Pickerill and Clayton 2004.

48 Whittington, forthcoming; Whittington 2001.

49 Lawrence 1990; Epp 1998.

50 Hirschl 2004, 11.
51 Ibid., 1.

52 Ibid., 12.

53 Ibid., 14.

54 Sweet 2000.

55 Epstein, Knight, and Shvetsova 2001.

56 Gibson, Caldeira, and Baird 1998.

57 Goldstein 2001.

58 Jacobsohn 2003.

59 Tarr 1998; Hall 2001.

60 Segal and Spaeth 2002; Spaeth and Segal 1999.

61 Pinello 2003.

62 Yalof 1999; Maltese 1995; Silverstein 1994; Goldman 1997. The seminal work in this literature is Abraham 1999.

63 Representative works include Barber and George 2001; Barber 1984; Moore 1996; Brandon 1998; Harris 1993.

64 Clinton 1989; Franck 1996; Wolfe 1986; Stoner 2003; Whittington 1999b.

65 Davis 1989; Brisbin 1997; Maveety 1996; Gerber 1999.

66 Downs 1989; Downs 1985.

67 Reed 2001.

68 Brigham 1987; Brigham 1996.

69 Fisher 1988; Levinson 1988; Burgess 1992; Agresto 1984; Devins 1996; Barber 1984. An earlier, too often neglected, work in this tradition is Morgan 1966.

70 Whittington 1999a.

71 Dinan 1998.

72 Gillman 1993. For a study of American free speech theory in this vein, see Graber 1991.

73 Smith 1985.

74 Novkov 2001. For a similar study in this vein, see Ritter 2002.

75 Baer 1999.

76 The syllabi reviewed for this essay were randomly collected by the staff of Perspectives on Politics and through a solicitation on the Law and Courts Discussion List. I did make sure that several representatives of all major schools of public law thought were included.

77 Members of the Princeton school of constitutional thought are the only political scientists who have at their disposal a casebook that (barely) reflects their perspective on constitutionalism. See Murphy, Fleming, and Barber 1995.

78 McCloskey 2000. These supplementary readings do not include any of the political science works discussed in the previous section.

79 Campbell et al. 1960.

80 Abrams v. United States, at 630 (Holmes, J., dissenting).

81 Abrams v. United States, at 626-29 (Holmes, J., dissenting). See Graber 1991, 110.

82 See, for example, Gertz v. Robert Welch, Inc. 
83 See Sartori 1962.

84 Maddox 1982.

85 Rossiter 1961, 35.

86 Elkin 2001, 1948; Graber 2001, 1971.

87 Coyle 1999.

88 Clayton and Gillman 1999.

89 Segal and Spaeth 2002.

90 Epstein and Knight 1998.

91 Gillman and Clayton 1999.

92 Yalof 1999.

93 McCloskey 2000.

94 Brinkley, Polsby, and Sullivan 1997.

95 Eskridge and Levinson 1998.

96 Goldwin and Schambra 1985.

97 Whittington 1999a.

98 Silverstein 1997.

99 Vile 1998.

100 Peretti 1999, 102.

101 Ibid., 219.

102 Ibid., 5.

103 Kahn 1994, 4.

104 For the elitist commitments of the framers, see Rossiter 1961, 43, 47, 82-83, 174, 455, 458-59.

105 Smith 1998.

106 Eskridge and Levinson 1998.

107 Sherry 1998, 93.

108 The negative radiations of the commerce clause refers to the circumstances under which the Supreme Court will strike down state laws that interfere with interstate commerce, even though those laws are not inconsistent with any national law. See, for example, Camps Newfound/Owatonna v. Town of Harrison.

109 The three-part Lemon test, named after Lemon v. Kurtzman (1971), addresses a state law conflicting with the Establishment Clause of the First Amendment. To be sustained, such laws must have a secular purpose; their primary effect must not be to advance religion, and they cannot foster an excessive entanglement between religion and the state.

110 Wechsler 1959.

111 Bickel 1962.

112 For a summary of the empirical presuppositions of grand constitutional theory, see Graber 2002.

113 Powell 1918, 647-48.

114 The sort of "nattering at justices" that takes place in the law reviews, such courses might emphasize, has so far not been an effective strategy for changing the direction of judicial decisions. Tushnet 1999, 155 .

\section{References}

Abraham, Henry J. 1999. Justices, presidents, and senators: A history of the U.S. Supreme Court appoint- ments from Washington to Clinton. 4th ed. Lanham, MD: Rowman and Littlefield.

Abrams v. United States. 250 U.S. 616 (1919).

Agresto, John. 1984. The Supreme Court and constitutional democracy. Ithaca: Cornell University Press.

Baer, Judith A. 1999. Our lives before the law: Constructing a feminist jurisprudence. Princeton: Princeton University Press.

Barber, Sotirios A. 1984. On what the Constitution means. Baltimore: Johns Hopkins University Press.

Barber, Sotirios A., and Robert P. George, eds. 2001. Constitutional politics: Essays on constitution making, maintenance, and change. Princeton: Princeton University Press.

Bickel, Alexander M. 1962. The least dangerous branch: The Supreme Court at the bar of politics. Indianapolis: Bobbs-Merrill.

Brandon, Mark E. 1998. Free in the world: American slavery and constitutional failure. Princeton: Princeton University Press.

Brigham, John. 1987. The cult of the Court. Philadelphia: Temple University Press.

. 1996. The constitution of interests: Beyond the politics of rights. New York: New York University Press.

Brinkley, Alan, Nelson W. Polsby, and Kathleen M. Sullivan. 1997. The new Federalist Papers: Essays in defense of the Constitution. New York: Twentieth Century Fund.

Brisbin, Richard A., Jr. 1997. Justice Antonin Scalia and the conservative revival. Baltimore: Johns Hopkins University Press.

Burgess, Susan R. 1992. Contest for constitutional authority: The abortion and war powers debates. Lawrence: University Press of Kansas.

Campbell, Angus, Philip E. Converse, Warren E. Miller, and Donald Stokes. 1960. The American voter. Chicago: University of Chicago Press.

Camps Newfound/Owatonna v. Town of Harrison. 520 U.S. 564 (1997).

Clayton, Cornell W. and Howard Gillman. 1999. Supreme Court decision-making: New institutionalist approaches. Chicago: University of Chicago Press.

Clinton, Robert Lowry. 1989. Marbury v. Madison and judicial review. Lawrence: University Press of Kansas.

Coyle, Dennis J. 1999. A constitutionalist political science. The Good Society 9 (1): 76-78.

Cross, Frank B. 1997. Political science and the new legal realism: A case of unfortunate interdisciplinary ignorance. Northwestern University Law Review 92 (1): 251-326.

. 1998. The justices of strategy. Duke Law Journal 48 (3): 511-70.

Dahl, Robert A. 1957. Decision-making in a democracy: The Supreme Court as a national policymaker. Journal of Public Law 6 (2): 279-95. 
Davis, Sue. 1989. Justice Rehnquist and the Constitution: The quest for a new federalism. Princeton: Princeton University Press.

Devins, Neal. 1996. Shaping constitutional values: Elected government, the Supreme Court, and the abortion debate. Baltimore: Johns Hopkins University Press.

Dinan, John J. 1998. Keeping the people's liberties: Legislators, citizens and judges as guardians of rights. Lawrence: University Press of Kansas.

Downs, Donald Alexander. 1985. Nazis in Skokie: Freedom, community, and the First Amendment. South Bend, IN: University of Notre Dame Press. 1989. The new politics of pornography. Chicago: University of Chicago Press.

Elkin, Stephen L. 2001. The constitutional theory of the commercial republic. Fordham Law Review 69 (5): 1933-68.

Epp, Charles R. 1998. The rights revolution: Lawyers, activists and supreme courts in comparative perspective. Chicago: University of Chicago Press.

Epstein, Lee, and Jack Knight. 1998. The choices justices make. Washington, DC: CQ Press.

- 1999. Mapping out the strategic terrain: the informational role of amici curiae. In Supreme Court decisionmaking: New institutional approaches, ed. C. W. Clayton and H. Gillman, 215-35. Chicago: University of Chicago Press.

Epstein, Lee, Jack Knight, and Andrew D. Martin. 2001. The Supreme Court as a strategic national policymaker. Emory Law Journal 50 (2): 583-611.

Epstein, Lee, Jack Knight, and Olga Shvetsova. 2001. The role of constitutional courts in the establishment and maintenance of democratic systems of government. Law and Society Review 35 (1): 117-63.

Epstein, Lee, and Thomas G. Walker. 1995. The role of the Supreme Court in American society: Playing the reconstruction game. In Contemplating courts, ed. Lee Epstein, 315-46. Washington, DC: CQ Press.

Eskridge, William N., Jr. 1991. Reneging on history? Playing the Court/Congress/President civil rights game. California Law Review 79 (3): 613-84.

Eskridge, William N., Jr., and Sanford V. Levinson, eds. 1998. Constitutional stupidities, constitutional tragedies. New York: New York University Press.

Ex parte McCardle. 74 U.S. 506 (1869).

Ex parte Milligan. 71 U.S. 2 (1866).

Feeley, Malcolm M., and Edward L. Rubin. 1998. Judicial policy making and the modern state: How the courts reformed America's prisons. New York: Cambridge University Press.

Fisher, Louis. 1988. Constitutional dialogues: Interpretation as political process. Princeton: Princeton University Press.

Fiss, Owen M. 1989. The law regained. Cornell Law Review 74 (2): 245-55.
Franck, Matthew J. 1996. Against the imperial judiciary: The Supreme Court vs, the sovereignty of the people. Lawrence: University Press of Kansas.

Franklin, Charles, and Liane C. Kosaki. 1989. Republican schoolmaster: The U.S. Supreme Court, public opinion, and abortion. American Political Science Review 83 (3): 751-71.

Friedman, Barry. 2002. The birth of an academic obsession: The history of the countermajoritarian difficulty, part five. Yale Law Journal 112 (2): 153-259.

Georgia v. Stanton. 73 U.S. 50 (1867).

Gerber, Scott Douglas. 1999. First principles: The jurisprudence of Clarence Thomas. New York: New York University Press.

Gertz v. Robert Welch, Inc. 418 U.S. 323 (1974).

Gibson, James L., Gregory A. Caldeira, and Vanessa A. Baird. 1998. On the legitimacy of national high courts. American Political Science Review 92 (2): 343-58.

Gillman, Howard. 1993. The Constitution besieged: The rise and demise of Lochner-era police powers jurisprudence. Durham, NC: Duke University Press.

- 2002. How political parties can use the courts to advance their agendas: Federal courts in the United States, 1875-1891. American Political Science Review 96 (3): 511-24.

Gillman, Howard, and Cornell W. Clayton, eds. 1999. The Supreme Court in American politics: new institutionalist interpretations. Lawrence: University Press of Kansas.

Goldman, Sheldon. 1997. Picking federal judges: Lower court selection from Roosevelt through Reagan. New Haven: Yale University Press.

Goldstein, Leslie Friedman. 2001. Constituting federal sovereignty: The European Union in comparative context. Baltimore: Johns Hopkins University Press.

Goldwin, Robert A. and William A. Schambra, eds. 1985. How does the Constitution secure rights? Washington, DC: American Enterprise Institute for Public Policy Research.

Graber, Mark A. 1991. Transforming free speech: The ambiguous legacy of civil libertarianism. Berkeley: University of California Press.

- 1993. The nonmajoritarian difficulty: Legislative deference to the judiciary. Studies in American Political Development 7 (1): 35-73.

- 2001. Social democracy and constitutional theory: An institutional perspective. Fordham Law Review 69 (5): 1969-87.

- 2002. Constitutional politics and constitutional theory: A misunderstood and neglected relationship. Law and Social Inquiry 27 (2): 309-38.

- 2003. Establishing judicial review: Marbury and the Judicial Act of 1789. Tulsa Law Review 38 (4): 609-50. 
Griffin, Stephen M. 1996. American constitutionalism: From theory to politics. Princeton: Princeton University Press.

Hall, Melissa Gann. 2001. State supreme courts in American democracy: Probing the myths of judicial reform. American Political Science Review 95 (2): 315-30.

Harris, William F., II. 1993. The interpretable Constitution. Baltimore: Johns Hopkins University Press.

Hirschl, Ran. 2004. Towards juristocracy: The origins and consequences of the new constitutionalism. Cambridge: Harvard University Press.

In re Debs. 158 U.S. 564 (1894).

Jacobsohn, Gary Jeffrey. 2003. Wheel of law: India's secularism in comparative constitutional context. Princeton: Princeton University Press.

Kahn, Ronald. 1994. The Supreme Court and constitutional theory, 1953-1993. Lawrence: University Press of Kansas.

Kalman, Laura. 1996. The strange career of legal liberalism. New Haven: Yale University Press.

Klarman, Michael J. 1994. Brown, racial change, and the civil rights movement. Virginia Law Review 80 (1): 7-150.

- 1996. Rethinking the civil rights and civil liberties revolutions. Virginia Law Review 82 (1): 1-67.

- 2001. The white primary rulings: a case study in the consequences of Supreme Court decisionmaking. Florida State University Law Review 29 (1): 55-107.

Knight, Jack, and Lee Epstein. 1996. On the struggle for judicial supremacy. Law and Society Review 30 (1): 87-120.

Lawrence, Susan E. 1990. The poor in court: The legal services program and Supreme Court decision making. Princeton: Princeton University Press.

Lemon v. Kurtzman. 403 U.S. 602 (1971).

Levinson, Sanford. 1988. Constitutional faith. Princeton: Princeton University Press.

- 2000. Preface to The American Supreme Court, by Robert G. McCloskey. 3rd ed. Chicago: University of Chicago Press.

Lucas v. South Carolina Coastal Council. 505 U.S. 1003 (1992).

Maddox, Graham. 1982. A note on the meaning of "constitution.” American Political Science Review 76 (4): 805-9.

Maltese, John Anthony. 1995. The selling of Supreme Court nominees. Baltimore: Johns Hopkins University Press.

Maltzman, Forrest, James F. Spriggs II, and Paul Wahlbeck. 2000. Crafting law on the Supreme Court: The collegial game. New York: Cambridge University Press.

Marbury v. Madison, 5 U.S. 137 (1803).

Marshall, Thomas R. 1989. Public opinion and the Supreme Court. Boston: Unwin Hyman.
Maveety, Nancy. 1996. Justice Sandra Day O'Connor: Strategist on the Supreme Court. Lanham, MD: Rowman and Littlefield.

McCann, Michael W. 1994. Rights at work: Pay equity reform and the politics of legal mobilization. Chicago: University of Chicago Press.

McCloskey, Robert G. 2000. The American Supreme Court. 3rd ed. Rev. Sanford Levinson. Chicago: University of Chicago Press.

McMahon, Kevin J. 2004. Reconsidering Roosevelt on race: How the presidency paved the road to Brown. Chicago: University of Chicago Press.

Michelman, Frank I. 1988. Law's republic. Yale Law Journal 97 (8): 1493-1537.

Mishler, William, and Reginald S. Sheehan. 1993. The Supreme Court as a counter-majoritarian institution? The impact of public opinion on Supreme Court decisions. American Political Science Review 87 (1) 87-101.

Mississippi v. Johnson. 71 U.S. 475 (1867).

Moore, Wayne D. 1996. Constitutional rights and powers of the people. Princeton: Princeton University Press.

Morgan, Donald G. 1966. Congress and the Constitution: A study in responsibility. Cambridge: Harvard University Press.

Murphy, Walter F. 1964. Elements of judicial strategy. Chicago: University of Chicago Press.

Murphy, Walter F., James E. Fleming, and Sotirios A. Barber. 1995. American constitutional interpretation. 2nd ed. Westbury, NY: Foundation Press.

Novkov, Julie. 2001. Constituting workers, protecting women: Gender, law, and labor in the Progressive Era and New Deal years. Ann Arbor: University of Michigan Press.

Peretti, Terri Jennings. 1999. In defense of a political Court. Princeton: Princeton University Press.

Pickerill, J. Mitchell, and Cornell W. Clayton. 2004. The Rehnquist Court and the political dynamics of Federalism. Perspectives on Politics 2 (2): 233-48.

Pinello, Daniel R. 2003. Gay rights and American law. New York: Cambridge University Press.

Pollock v. Farmers' Loan and Trust Co. 158 U.S. 601 (1895).

Powe, Lucas A., Jr. 2000. The Warren Court and American politics. Cambridge: Harvard University Press.

Powell, Thomas Reed. 1918. The logic and rhetoric of constitutional law. Journal of Philosophy 15 (November): 645-58.

Reed, Douglas S. 2001. On equal terms: The constitutional politics of educational opportunity. Princeton: Princeton University Press.

Ritter, Gretchen. 2002. Jury service and women's citizenship before and after the Nineteenth Amendment. Law and History Review 20 (3): 479-515. 
Rogers, James R. 2001. Information and judicial review: A signaling game of legislative-judicial interaction. American Journal of Political Science 45 (1): 84-99.

Rosenberg, Gerald N. 1991. The hollow hope: Can courts bring about social change? Chicago: University of Chicago Press.

-2000. Bringing politics back in. Northwestern University Law Review 95 (Fall): 309-26.

Rossiter, Clinton L., ed. 1961. The Federalist Papers: Alexander Hamilton, James Madison, John Jay. New York: New American Library.

Sartori, Giovanni. 1962. Constitutionalism: A preliminary discussion. American Political Science Review 56 (4): 853-64.

Schultz, David A., ed. 1998. Leveraging the law: Using the courts to achieve social change. New York: Peter Lang.

Segal, Jeffrey A., and Harold J. Spaeth. 1993. The Supreme Court and the attitudinal model. New York: Cambridge University Press.

- 2002. The Supreme Court and the attitudinal model revisited. New York: Cambridge University Press.

Shapiro, Martin. 1983. Recent developments in political jurisprudence. Western Political Quarterly 36 (4): 541-48.

-1989. Political jurisprudence, public law, and post-consequentialist ethics: Comment on Professors Barber and Smith. Studies in American Political Development 3 (1): 88-102.

Sherry, Suzanna. 1998. Our unconstitutional Senate. In Constitutional stupidities, constitutional tragedies, ed. William N. Eskridge Jr. and Sanford V. Levinson. 95-97. New York: New York University Press.

Silverstein, Gordon. 1997. Imbalance of powers: Constitutional interpretation and the making of American foreign policy. New York: Oxford University Press.

Silverstein, Mark. 1994. Judicious choices: The new politics of Supreme Court confirmations. New York: W. W. Norton.

Silverstein, Mark, and Benjamin Ginsberg. 1987. The Supreme Court and the new politics of judicial power. Political Science Quarterly 102 (3): 371-88.

Smith, Rogers M. 1985. Liberalism and American constitutional law. Cambridge: Harvard University Press.

1997. Civil ideals: Conflicting visions of citizenship in U.S. history. New Haven: Yale University Press.

- 1998. The inherent deceptiveness of constitutional discourse: A diagnosis and prescription. In NOMOS XL: Integrity and Conscience, ed. Ian Shapiro and Robert Adams, 218-54. New York: New York University Press.

Spaeth, Harold J., and Jeffrey A. Segal. 1999. Majority rule or minority will: Adherence to precedent on the
U.S. Supreme Court. New York: Cambridge University Press.

Stearns, Maxwell L. 2000. Constitutional process: A social choice analysis of Supreme Court decision making. Ann Arbor: University of Michigan Press.

Stoner, James R. 2003. Common law liberty: Rethinking American constitutionalism. Lawrence: University Press of Kansas.

Sunstein, Cass R. 1999. One case at a time: Judicial minimalism on the Supreme Court. Cambridge: Harvard University Press.

Sweet, Alec Stone. 2000. Governing with judges: Constitutional politics in Europe. New York: Oxford University Press.

Tarr, G. Alan. 1998. Understanding state constitutions. Princeton: Princeton University Press.

Tocqueville, Alexis de. 1990. Democracy in America, ed. Phillips Bradley. New York: Vintage Books.

Tushnet, Mark V. 1999. Taking the Constitution away from the courts. Princeton: Princeton University Press.

United States v. E.C. Knight Co. 156 U.S. 1 (1895).

Vile, M. J. C. 1998. Constitutionalism and the separation of powers. 2nd ed. Indianapolis, IN: Liberty Fund.

Wabash, St. Louis \& Pacific Railway Co. v. Illinois. 118 U.S. 557 (1886).

Wechsler, Herbert. 1959. Toward neutral principles of constitutional law. Harvard Law Review 73 (1): 1-35.

Whittington, Keith E. 1999a. Constitutional construction: Divided powers and constitutional meaning. Cambridge: Harvard University Press.

- 1999 b. Constitutional interpretation: Textual meaning, original intent, and judicial review. Lawrence: University Press of Kansas.

- 2001. The political foundations of judicial supremacy. In Constitutional politics: Essays on constitution making, maintenance and change, ed. Sotirios A. Barber and Robert P. George, 261-97. Princeton: Princeton University Press.

- 2003. Legislative sanctions and the strategic environment of judicial review. I-Con: The International Journal of Constitutional Law 1 (3): 446-74.

- Forthcoming. To say what the law is: Judicial authority in a political context. Princeton: Princeton University Press.

Wolfe, Christopher. 1986. The rise of modern judicial review: From constitutional interpretation to judgemade law. New York: Basic Books.

Yalof, David Alistair. 1999. Pursuit of justices: Presidential politics and the selection of Supreme Court nominees. Chicago: University of Chicago Press. 